\title{
Rethinking schizophrenia through the lens of evolution: shedding light on the enigma
}

\author{
Ariel Ernesto Cariaga-Martinez $z^{\ddagger}$ Kilian Jesús Gutiérrez \\ ‡ Laboratory of Neuroscience Elena Pessino Gómez del Campo, Madrid, Spain
}

Corresponding author: Raúl Alelú-Paz (ralelu@canismajoris.es)

Received: 18 Jul 2018 | Published: 19 Jul 2018

Citation: Cariaga-Martinez A, Gutiérrez K, Alelú-Paz R (2018) Rethinking schizophrenia through the lens of evolution: shedding light on the enigma. Research Ideas and Outcomes 4: e28459.

\begin{abstract}
Schizophrenia refers to a complex psychiatric illness characterized by the heterogenic presence of positive, negative and cognitive symptoms occurring in all human societies. The fact that the disorder lacks a unifying neuropathology, presents a decreased fecundity of the affected individuals and has a cross-culturally stable incidence rate, makes it necessary for an evolutionary explanation that fully accounts for the preservation of "schizophrenic genes" in the global human genepool, explaining the potential sex differences and the heterogeneous cognitive symptomatology of the disorder and is consistent with the neuropsychological, developmental and evolutionary findings regarding the human brain. Here we proposed a new evolutionary framework for schizophrenia that is consistent with findings presented in different dimensions, considering the disorder as a form of brain functioning that allows us to adapt to the environment and, ultimately, maintain the survival of the species. We focus on the epigenetic regulation of thalamic interneurons as a major player involved in the development of the clinical picture characteristic of schizophrenia.
\end{abstract}

\section{Keywords}

schizophrenia; evolution; human thalamus; interneurons 


\section{Introduction}

Schizophrenia is considered as a debilitating genetic psychiatric disorder characterized by the presence of a constellation of symptoms that fits into three categories that affects all the cognitive domains described to date. In the last ten years, the number of papers about the molecular biology, anatomy, physiology or cognition, among other aspects, of schizophrenia has increased until reaching an average of, approximately, 5.000 works per year. Most of which have been presented as major breakthroughs that are impossible to replicate, resulting in a data accumulation that clearly reflects a sign of uncertainty and confusion (Maj 2011). While Maj suggests that in our understanding of the pathophysiology of schizophrenia we must ask ourselves if we are on the wrong or on the right track (Maj 2011), we think that we need to include different aspects of the two tracks to understand why we fail when we try to understand and explain, in Jaesperian terms, this complex phenomenon.

We cannot deny that we are facing a complex issue with several edges, many of them enigmatic (Alelu-Paz et al. 2016) which, together, create an unresolved pool of questions such as: Why has natural selection allowed genes to persist in the human genome that increase the likelihood of suffering schizophrenia, despite its reproductive disadvantage? Can we describe a disease entity corresponding to what we call schizophrenia? Is there an exact correlation between genotype and phenotype? What role do environmental factors play in schizophrenia etiology? Is there a link between brain malfunctioning and schizophrenia symptoms?

Let's start with one of the most significant contributors in the past 25 years: the neurobiology approach.

\section{What do we know about the neurobiology of schizophrenia?}

Classically, we define schizophrenia as a complex psychiatric illness occurring in all human societies with approximately the same incidence (Crow 1995b) and with a high heritability (between 60 and 80\%) (Lichtenstein et al. 2009). Adolescence and early adulthood represent the critical time period when the first symptoms appear, with a median lifetime prevalence of 4.0 per 1000 that seems to remain stable across generations (Srinivasan et al. 2016), a morbid risk of 7.2 per 1000 (Cariaga-Martinez et al. 2016), a reduced fecundity of, around, 50\% compared to healthy individuals (Brune 2004, Power et al. 2013) and mortality rates significantly greater than in the general population (Liu et al. 2017, Saha et al. 2007).

The idea that schizophrenia is a brain disorder and, therefore, it is possible to study the neurobiological bases of the clinical symptoms that the diagnosis is based on, it has been translated into a paradigm shift, giving primacy to neurochemical and molecular perspectives to the detriment of those that understand it as a psychological reactions to stressful environments (Mathalon and Ford 2012). Both approaches have always been considered, in some way, incompatible and, both, largely unsuccessful. It is important to 
highlight that schizophrenia is influenced by a set of several genetic and environmental factors that genetics alone cannot explain. What's more, neurobiology has not been able, until today, to explain the phenomenon; we could try to explain the failure of the genetic and epigenetic approaches to factors as diverse as small samples, questionable reliability and validity of measurements, medication confounds, failure to distinguish state and trait effects, correlation-causation ambiguity or, even, false data (Cariaga-Martinez and AleluPaz 2016, Mathalon and Ford 2012), but in our opinion, the lack of a theoretical framework that includes and relates clinical, psychological, social and biological variables could explain the sterile accumulation of data in the last years. Although several genes have been implicated and various susceptibility loci for the disorder such as RELN, PLXNA2, ZNF804A or NRG1 (Edwards et al. 2016, Mah et al. 2006, O'Donovan et al. 2008, Shifman et al. 2008), to date, no candidate gene has been conclusively linked to schizophrenia (Alelu-Paz et al. 2016, Cariaga-Martinez et al. 2016, Pearlson and Folley 2008), explaining only a small fraction of the total amount of genetic variation assumed to underlie the disorder and never replicated across populations ( $\mathrm{Ng}$ et al. 2009, van Dongen and Boomsma 2013). The same could be said for endophenotype analysis (Gottesman and Gould 2003, Owen et al. 2005, Hosák and Hosakova 2015), quantitative trait loci approach (Cariaga-Martinez et al. 2016, Kim et al. 2014, Cariaga-Martinez and Alelu-Paz 2017) and structural and functional studies. In relation to the latter, although several macroscopic findings have been described, some of them presented as major ones, up to now, it is not possible to ensure that there is a clear neuropathological signature for the disorder (Cariaga-Martinez et al. 2016, Harrison and Weinberger 2004); moreover, the positive results in this regard are considered as incomplete, inconsistent, contradictory, nonsignificant and nonspecific (Harrison and Weinberger 2004).

Do these results imply that we must abandon the neurobiological approach in the study of schizophrenia? The answer is, clearly, no. We think we must reformulate our ideas to understand what schizophrenia is. In this regard, evolutionary approaches represent an interesting theoretical framework to face the paradox that accompanies the disorder.

\section{Is there an evolutionary framework for schizophrenia?}

We can establish two main classical explanations about the genetic etiology of schizophrenia: the presence of a single, partially dominant gene with low penetrance translated into slight physiological advantages (Srinivasan et al. 2016, Huxley et al. 1964) or many susceptibility genes each one with a small individual effect, which can aggregate by chance to constitute increased risk (Pearlson and Folley 2008, Cannon 2005). Recently, it has been proposed that schizophrenia is the result of human polygenic adaptation, including genes such as DPYD, ZNF804A, NRXN1, NRG3 or VRK2, among others (Srinivasan et al. 2016). None of them have been able to find consistent results, so it is necessary to rethink new strategies to face the problem. In this respect, what does evolution have to say? 
Schizophrenia represents an evolutionary paradox: genetic variants that cause predisposition to the disorder persist in the population, despite the fitness reduction in affected individuals (van Dongen and Boomsma 2013). Its evolutionary origins are, up to date, mysterious (Pearlson and Folley 2008) although the literature has provided a host of evolutionary hypotheses trying to clarify the enigma (Polimeni and Reiss 2003). Briefly, these proposals range from those that focus on the survival advantage of heterozygous gene carriers (Brune 2004, Huxley et al. 1964, Erlenmeyer-Kimling 1968, Carter and Watts 1971), through to others that concentrate on the impaired ontogenetic neurodevelopment in the disorder (Brune 2004, Randall 1983, Saugstad 1989, Burns 2004), finishing with those that suggest that schizophrenia represents a trade-off of the evolution of human sociality (Crow 1995b, Brune 2004, Kuttner et al. 1967, Crow 1995a, Stevens and Price 1996). The common denominator to all of them is to consider that the disorder does not represent any evolutionary advantage for our species.

According to Brüne, all of these evolutionary-based explanations are informative only if they account for plausible mechanisms for the preservation of "schizophrenic genes" in the global human genepool, explain the potential sex differences and the heterogeneous symptomatology of the disorder and are consistent with the neuropsychological, developmental and evolutionary findings regarding the human brain (Brune 2004). We think we must add other core facts related to clinical and social aspects, such as the age of onset of the disorder, the absence of structural, biochemical or molecular correlations, the presence of cognitive alterations in all patients and the evidence of a reduced fecundity and increased mortality compared to healthy individuals.

Here we propose a new evolutionary explanation of schizophrenia which aims to conciliate the data now available that may serve as a useful framework for research.

\section{The core facts of schizophrenia}

It is evident that genetic variants associated with reduced fitness should be under negative selection pressure, but natural selection has not eliminated them. According to the core facts pointed out before, we need to explain, at least, the following replicated findings present in different dimensions:

From a clinical point of view, the age at onset of schizophrenia, that can be defined in different ways, including age at first admission, age at first positive symptoms and age at first contact with healthcare professionals (Immonen et al. 2017). The data available indicates that the mean age of onset was 21.44 years (SD 8.07) with an earlier age at onset in males (Hare et al. 2010, Eranti et al. 2013), although these results are not consistent when the schizophrenia spectrum disorder diagnosis is included Talonen et al. 2017. Secondly, the cognitive impairment, which is heterogeneity and moderately to severely impaired in patients with schizophrenia, representing the prime driver of the significant disabilities in occupational, social, and economic functioning in these patients affecting attention, memory, reasoning, social cognition and processing speed (Elvevag and Goldberg 2000, van Os et al. 2010, Akbarian 2014, Harvey 2013). The heterogeneous symptomatology of the disorder could be due to methodological problems (i.e. small 
samples or unclear clinical histories) (Fioravanti et al. 2005), the clinical diversity of patients included in the studies or, finally, the statistical analysis performed (Fioravanti et al. 2012).

Related to neurobiology, the core fact related to schizophrenia is the absence of reproducibility. As we have suggested, there are many contradictory results that make it impossible to establish a structural, biochemical or molecular pathognomonic pattern of the disease (Maj 2011, Cariaga-Martinez et al. 2016, Cariaga-Martinez and Alelu-Paz 2016, Chua and McKenna 1995, Thune et al. 2001, Keshavan et al. 2011, Shepherd et al. 2012, Dorph-Petersen and Lewis 2017).

Finally, epidemiological studies consider environmental and psychosocial stressors as risk factors for the development of the disorder (Corcoran et al. 2002, Corcoran et al. 2003, Betensky et al. 2008, Tost et al. 2015, Howes et al. 2017). Secondly, the substantial fecundity disadvantage of people with a diagnosis of schizophrenia, reduced to about $50 \%$ compared to healthy individuals (Crow 1995b, Brune 2004, Power et al. 2013, Markow 1994, McGrath et al. 1999) and, to finish with a significantly increased risk of mortality compared to healthy individuals (Saha et al. 2007, Liu et al. 2017, Tsuang and Simpson 1988, Allebeck 1989, Brown 1997, Harris and Barraclough 1998, Olfson et al. 2015).

Previous evolutionary hypotheses have addressed some of these questions trying to explain the constant incidence rates of the disorder independently of the culture or the environment, despite the fact that, as we have indicated before, people suffering from schizophrenia have a reduced fecundity and an increased risk of mortality compared to the general population (Brune 2004). We could ask ourselves why natural selection maintains susceptibility genes of schizophrenia if the apparent reproductive disadvantage is not compensated for, by any survival advantages; that is, the evolutionary paradox.

\section{An evolutionary explanation of schizophrenia: shedding light on the enigma}

Our hypothesis suggests that schizophrenia is as a form of brain functioning, among many, that allows us to adapt to the environment and, ultimately, maintain the survival of our species. As Darwin suggested, "variations neither useful nor injurious would not be affected by natural selection and would be left either as a fluctuating element, as perhaps is seen in certain polymorphic species, or would ultimately become fixed, owing to the nature of the organism, and the nature of the conditions.... Due to this struggle, variations, however slight and from whatever proceeding course, if they are to any degree profitable to the individuals of a species, in their infinitely complex relations to other organic beings and to their physical conditions of life, will tend to the preservation of such individuals, and will generally be inherited by the offspring" (Darwin 1859). In other words, the process of natural selection preserves genetic variants associated with survival and reproductive advantage, while genetic variants associated with low fitness are eliminated from the genepool (van Dongen and Boomsma 2013). This, implies, that individual properties are either favorable, or injurious, or neutral under a certain set of conditions (den Boer 1999). 
Explaining schizophrenia as an adaptation to the environment has been the object of significant criticism (Brune 2004, van Dongen and Boomsma 2013, Dubrovsky 2002), suggesting that, although there is an association between schizophrenia and social and musical skills, creativity and intelligence or, even, between schizophrenia and advantageous somatic characteristics (van Dongen and Boomsma 2013), these proposals do not account for the negative effects of this disorder to affected individuals. What's more, we should consider that a trait could be prevalent in a population due to mechanisms such as random mutation, genetic drift or segregation distortion but not for its adaptive advantages (Lane and Luchins 1988). In our opinion, considering schizophrenia as an adaptation to the environment has the same validity and reliability as the hypotheses that consider the disorder as an evolutionary disadvantage. Moreover, the latter have not proposed a theoretical framework that includes the experimental findings obtained to date and are thus limited to the accumulation of data that, as we have said throughout the manuscript, are inconsistent, incoherent and not replicable.

If we consider schizophrenia as an adaptive extreme behavior, can we answer all the questions that remain unknown?

Firstly, we must consider that there is no single way of mind functioning, that is, there is no one way in which our brain faces the environment. The human brain is a highly contextsensitive system, enabling behavioral flexibility in the face of constantly changing environmental challenges (van Os et al. 2010). Schneider already pointed this out several decades ago when he developed his proposal for a clinical psychopathology that described within the general population normal and abnormal psychic reactions to experiences; the latter differ from the first in strength and duration, and included anxiety, depressions, delusions, paranoia, rage and jealousy (Muleh and Carpenter 1973, Schneider 1959). Following this same line, recently, several authors indicate the existence of a subclinical presentation of psychosis, commonly referred to as psychosis proneness, psychotic experiences, schizotypy or at-risk mental states (Siever et al. 1993, Chapman et al. 1994, Claridge 1997, Crow 1998, Kwapil 1998, Verdoux et al. 1998b, van Os et al. 2000, Stefanis et al. 2002, Vollema et al. 2002, Yung et al. 2003, van Os et al. 2009, Verdoux et al. 1998a) that suggests that even though the prevalence of the clinical disorder is low, the prevalence of the symptoms can conceivably be much higher, even when not considered clinically relevant but persistent (van Os et al. 2009, Collip et al. 2013). Therefore, we must admit the existence of a psychosis phenotype expressed along a continuum ranging from attributes widely distributed in the population, ranging from mild subclinical psychotic experiences to full-blown psychotic disorders (Crow 1995b, Schneider 1959, Bebbington 2015, van der Steen et al. 2018) including the daily life stress reactivity as a possible trigger of the disorder in the analysis, since it is considered a marker of sensitization, which in turn has been proposed as the mechanism underlying increased liability to develop persistent psychotic experiences (Collip et al. 2013, Kaymaz et al. 2012).

Therefore, if we understand schizophrenia as an adaptive variation of brain functioning conditioned by the presence of stressful life events, we can explain why natural selection allows schizophrenic genes to persist in the human genome, independently of the decrease in fecundity rates and increase in mortality rates in this population. 
Secondly, what about the clinical aspects of the disorder?

Regarding the age at onset of schizophrenia, the results depend, to a great extent, on the diagnostic criteria used, although several studies suggest that there are gender differences in the normal development and maturation of the brain during adolescence, and this period brings about typical gender differences in the epidemiology of mental disorders, including schizophrenia (Talonen et al. 2017, Paus 2010, Paus et al. 2008, Birmaher et al. 2007, Connolly et al. 2007, Fombonne 2009), for example the differences between males and females in their physiological stress response (Bale and Epperson 2015).

However, cognitive impairment is one of the well-recognized characteristics and wideranging deficits across all domains of ability in schizophrenia (Neu et al. 2017). The impairments are present before the emergence of positive symptoms and appear stable from the first episode until middle age illness (Davidson et al. 1999, Cornblatt and Erlenmeyer-Kimling 1985, Rund 1998). It is well documented that the cerebral cortex has a key role in cognition (Zola-Morgan and Squire 1993, Goel et al. 1998, Miller 2000, Muller and Knight 2006, Hickok 2009, Apps et al. 2016, Filley and Fields 2016, Lockwood 2016, Millan et al. 2016, Ramirez-Cardenas and Viswanathan 2016, Rosenthal and Soto 2016, Eichenbaum 2017) so we would expect a significant structural impairment in the cortex of schizophrenic patients. However, the results obtained are contradictory, inconsistent and controversial (Weinberger and Berman 1998, Harrison 1999, Manoach 2003, Sayo et al. 2012), thus allowing us to conclude that schizophrenia is characterized by a lack of a unifying neuropathology (Cariaga-Martinez et al. 2016, Catts et al. 2013, Dorph-Petersen and Lewis 2011), at least as far as the cerebral cortex is concerned.

So, how can we explain this cognitive impairment without significant structural impairment in the cerebral cortex of schizophrenic patients? Should we go beyond the cortex?

Let's focus on a subcortical structure where further knowledge has modified our traditional view of how the brain processes information: the thalamus.

This evolutionary conserved structure has extensive reciprocal connections to cortical regions (Nakajima and Halassa 2017). It is located near the middle of the brain and it can be divided into dorsal and ventral divisions related to embryonic origin (Sherman 2017), being involved in a wide range of cognitive, sensorymotor and limbic functions acting as a gate or a high pass filter which represents a bottleneck for the transfer of information to cortex in an efficient way (Sherman 2017, Alelu-Paz and Gimenez-Amaya 2008, Connelly et al. 2015). Moreover, several authors suggest that its function cannot be dissociated from that of the cortex in attention, perception, consciousness or the integration of thought processes (Jones 1997, Penner et al. 2018), that is, those that are impaired in schizophrenia.

We suggest that the thalamus acts as a gate: by gating we refer the fact that one type of thalamic cell- relay cells- receive strong inhibitory GABAergic inputs from local and external sources; if these inputs are very active, the gate is shut and there is no relay to cortex, if the inputs are silent, the gate is open, and if the inputs are moderately active, the gate is 
partially open (Sherman 2017). From the above derives the importance that interneurons have in the control of the flow of information to the cortex and the crucial role that is played by the thalamus in several cognitive functions such as learning (Bradfield et al. 2013, Habib et al. 2013), memory processes (Alelu-Paz and Gimenez-Amaya 2008, Alelu-Paz and Gimenez-Amaya 2007, Baxter 2013, Funahashi 2013, Jankowski et al. 2013, Mitchell and Chakraborty 2013, Saalmann 2014), set-shifting (Bradfield et al. 2013, Saalmann 2014, Minamimoto et al. 2014), language (Klostermann et al. 2013), movement monitoring and control (Alelu-Paz and Gimenez-Amaya 2008, Minamimoto et al. 2014, Ostendorf et al. 2013, Prevosto and Sommer 2013).

As a first approach, it can be hypothesized that a structural impairment in the thalamus (i.e. volume, total cell number), could underlay the cognitive deficit characteristic of schizophrenia, according to its function as a mediator between the external world and the cerebral cortex controlling the flow of information from below to top (Sherman 2017) or, even, due to its role in natural recovery of cognitive impairment after brain injury (Munivenkatappa et al. 2016), but the data available up to now is inconsistent and contradictory (Dorph-Petersen and Lewis 2017) and, therefore, it is mandatory to discard this possibility.

However, what can be said about function? Beyond the structure, recent studies suggest an altered thalamo-cortical pattern of connectivity in schizophrenia which translate into an increased thalamic connectivity with all sensory-motor cortices (Anticevic et al. 2014) and a reduced total connectivity with orbitofrontal cortex, prefrontal cortex, striatum, anterior cingulate cortex, cerebellum, parahippocampal gyrus and inferior parietal cortex (Anticevic et al. 2014, Marenco et al. 2012, Cho et al. 2016, Giraldo-Chica et al. 2018, Hamoda et al. 2018, Zaytseva et al. 2018), being present this aberrant thalamo-cortical connectivity in the early stages of the disorder (Hamoda et al. 2018) and, in some cases, related to symptoms that are characteristic of schizophrenia (Zaytseva et al. 2018, Li et al. 2017).

We hypothesized that this aberrant thalamo-cortical connectivity is a consequence of the presence of stressful life events and, more specifically, we suggest that the management of these events by the thalamus fails due to the shutdown of interneurons, with the corresponding absence of control of the flow of information to cortex. The latter, the cortex, as a physical system, would not be able to manage the information without the thalamus functioning correctly, hence the appearance of alterations in the processing of information that result in the cognitive alterations that are characteristic of the disorder.

The consequence of the aforementioned hypothesis is evident: the clinical picture of schizophrenia is the trade-off that some individuals pay for adapting to the environment.

\section{Moving beyond theory: an experimental proposal}

How can we check the theory proposed? As we previously pointed out, our theory accounts for plausible mechanisms for the preservation of "schizophrenic genes" in the global human genepool, explaining the heterogeneous cognitive symptomatology of the 
disorder, and is consistent with the neuropsychological, developmental and evolutionary findings regarding the human brain, at least with those that are consistently linked to the disorder. Moreover, it provides an answer to the questions posed by the different epidemiological studies on schizophrenia.

Regardless, beyond the theory, we think it necessary to provide an experimental approach that allows us to refute what we propose here.

Due to the fact that we consider the thalamic interneurons as the main actor that, in the presence of certain stressful events of daily life, stop working correctly, altering thalamocortical connectivity patterns, we think we need to focus on the epigenetic signatures that are specific to each cell population and, more specifically, of those genes involved in the interneuron functioning, such as SLITRK3 or PTPRD, both regulating the number of functional inhibitory synapses (Takahashi et al. 2012). We would expect, as null hypothesis, a non-altered epigenetic pattern (DNA methylation or histone modifications) of these genes in schizophrenic interneurons compared to healthy interneurons. We focus on epigenetics because the stress-vulnerability model of etiology assumes that genetic factors operate by making individuals selectively vulnerable to environmental risks. Accordingly, epigenetics refers to the interplay between environment and genes that initiate and maintain heritable patterns of gene expression and function without changing the sequence of the genome (Urdinguio et al. 2009). It is considered that epigenetic processes are highly dynamic even within an individual, being involved in the regulation of many developmental processes including the programs of gene expression that result in the development of different organs, tissues (Shipony et al. 2014) and, even, among different subpopulations of a given cell type (Iwamoto et al. 2011, Kozlenkov et al. 2014, Kozlenkov et al. 2016), i.e. interneurons and projection neurons. Therefore, we can conclude that these specific epigenetic markers may help to explain brain region-specific and cell type-specific differences in gene transcription, and are critical in order to analyze the degree to which brain epigenetic signatures might be altered in severe mental diseases, such as schizophrenia (Ladd-Acosta et al. 2007).

\section{Acknowledgements}

This study has been supported by grants from the Canis Majoris Foundation (Madrid, Spain; www.canismajoris.es).

\section{Hosting institution}

Madrid Scientific Park. $7^{\text {th }}$, Faraday St. (ZIP: 28049). Madrid. Spain.

\section{Author contributions}

APR conceive the manuscript and CMA, GKJ and APR wrote the manuscript. 


\section{Conflicts of interest}

The founding sponsors had no role in the design of the study; in the collection, analyses, or interpretation of data; in the writing of the manuscript, and in the decision to publish the results.

\section{References}

- $\quad$ Akbarian S (2014) Epigenetic mechanisms in schizophrenia. Dialogues in Clinical Neuroscience 16 (3): 405-417.

- $\quad$ Alelu-Paz R, Gimenez-Amaya JM (2007) Chemical parcellation of the anterior thalamic nuclei in the human brain. Journal of Neural Transmission 114 (8): 969. https:// doi.org/10.1007/s00702-007-0633-8

- $\quad$ Alelu-Paz R, Gimenez-Amaya JM (2008) The mediodorsal thalamic nucleus and schizophrenia. Journal of Psychiatry \& Neuroscience 33 (6): 489-498.

- Alelu-Paz R, Carmona FJ, Sanchez-Mut JV, Cariaga-Martinez A, Gonzalez-Corpas A, Ashour N, Orea MJ, Escanilla A, Monje A, Guerrero Marquez C, Saiz-Ruiz J, Esteller M, Ropero S (2016) Epigenetics in schizophrenia: A pilot study of global DNA methylation in different brain regions associated with higher cognitive functions. Frontiers in Psychology 7: 1496. https://doi.org/10.3389/fpsyg.2016.01496

- $\quad$ Allebeck P (1989) Schizophrenia: a life-shortening disease. Schizophrenia Bulletin 15 (1): 81-99. https://doi.org/10.1093/schbul/15.1.81

- Anticevic A, Cole MW, Repovs G, Murray JD, Brumbaugh MS, Winkler AM, Savic A, Krystal JH, Pearlson GD, Glahn DC (2014) Characterizing thalamo-cortical disturbances in schizophrenia and bipolar illness. Cerebral Cortex 24 (12): 3116-3130. https://doi.org/10.1093/cercor/bht165

- $\quad$ Apps MA, Rushworth MF, Chang SW (2016) The anterior cingulate gyrus and social cognition: Tracking the motivation of others. Neuron 90 (4): 692-707. https:// doi.org/10.1016/j.neuron.2016.04.018

- Bale TL, Epperson CN (2015) Sex differences and stress across the lifespan. Nature Neuroscience 18 (10): 1413-1420. https://doi.org/10.1038/nn.4112

- Baxter MG (2013) Mediodorsal thalamus and cognition in non-human primates. Frontiers in Systems Neuroscience 7 https://doi.org/10.3389/fnsys.2013.00038

- Bebbington P (2015) Unravelling psychosis: psychosocial epidemiology, mechanism, and meaning. Shanghai Archives of Psychiatry 27 (2): 70-81. https://doi.org/10.11919/ j.issn.1002-0829.215027

- Betensky JD, Robinson DG, Gunduz-Bruce H, Sevy S, Lencz T, Kane JM, Malhotra AK, Miller R, McCormack J, Bilder RM, Szeszko PR (2008) Patterns of stress in schizophrenia. Psychiatry Research 160 (1): 38-46. https://doi.org/10.1016/ j.psychres.2007.06.001

- $\quad$ Birmaher B, Brent D, Quality Issues AWGo, Bernet W, Bukstein O, Walter H, Benson RS, Chrisman A, Farchione T, Greenhill L, Hamilton J, Keable H, Kinlan J, Schoettle U, Stock S, Ptakowski KK, Medicus J (2007) Practice parameter for the assessment and treatment of children and adolescents with depressive disorders. Journal of the 
American Academy of Child \& Adolescent Psychiatry 46 (11): 1503-26. https:// doi.org/10.1097/chi.0b013e318145ae1c

- $\quad$ Bradfield LA, Hart G, Balleine BW (2013) The role of the anterior, mediodorsal, and parafascicular thalamus in instrumental conditioning. Frontiers in Systems Neuroscience 7 https://doi.org/10.3389/fnsys.2013.00051

- Brown S (1997) Excess mortality of schizophrenia. A meta-analysis. The British Journal of Psychiatry 171: 502-508. https://doi.org/10.1192/bjp.171.6.502

- Brune M (2004) Schizophrenia-an evolutionary enigma? Neuroscience \& Biobehavioral Reviews 28 (1): 41-53. https://doi.org/10.1016/j.neubiorev.2003.10.002

- Burns JK (2004) An evolutionary theory of schizophrenia: cortical connectivity, metarepresentation, and the social brain. Behavioral and Brain Sciences 27 (6): 831-855.

- $\quad$ Cannon TD (2005) The inheritance of intermediate phenotypes for schizophrenia. Current Opinion in Psychiatry 18 (2): 135-40. https://

doi.org/10.1097/00001504-200503000-00005

- $\quad$ Cariaga-Martinez A, Alelu-Paz R (2016) False data, positive results in neurobiology: moving beyond the epigenetics of blood and saliva samples in mental disorders. Journal of Negative Results in Biomedicine 15: 21. https://doi.org/10.1186/s12952-016-0064-X

- $\quad$ Cariaga-Martinez A, Saiz-Ruiz J, Alelu-Paz R (2016) From Linkage Studies to Epigenetics: What We Know and What We Need to Know in the Neurobiology of Schizophrenia. Frontiers in Neuroscience 10 https://doi.org/10.3389/fnins.2016.00202

- $\quad$ Cariaga-Martinez A, Alelu-Paz R (2017) Rethinking the epigenetic framework to unravel the molecular pathology of schizophrenia. International Journal of Molecular Sciences 18 (4): 790. https://doi.org/10.3390/ijms18040790

- $\quad$ Carter M, Watts CA (1971) Possible biological advantages among schizophrenics' relatives. The British Journal of Psychiatry 118 (545): 453-460. https://doi.org/10.1192/ bip.118.545.453

- $\quad$ Catts VS, Fung SJ, Long LE, Joshi D, Vercammen A, Allen KM, Fillman SG, Rothmond DA, Sinclair D, Tiwari Y, Tsai SY, Weickert TW, Shannon Weickert C (2013) Rethinking schizophrenia in the context of normal neurodevelopment. Frontiers in Cellular Neuroscience 7 https://doi.org/10.3389/fncel.2013.00060

- Chapman LJ, Chapman JP, Kwapil TR, Eckblad M, Zinser MC (1994) Putatively psychosis-prone subjects 10 years later. Journal of Abnormal Psychology 103 (2): 171-183. https://doi.org/10.1037/0021-843X.103.2.171

- $\quad$ Cho KI, Shenton ME, Kubicki M, Jung WH, Lee TY, Yun JY, Kim SN, Kwon JS (2016) Altered Thalamo-Cortical White Matter Connectivity: Probabilistic Tractography Study in Clinical-High Risk for Psychosis and First-Episode Psychosis. Schizophrenia Bulletin 42 (3): 723-731. https://doi.org/10.1093/schbul/sbv169

- $\quad$ Chua SE, McKenna PJ (1995) Schizophrenia - a brain disease? A critical review of structural and functional cerebral abnormality in the disorder. The British Journal of Psychiatry 166 (5): 563-582. https://doi.org/10.1192/bjp.166.5.563

- $\quad$ Claridge G (1997) Schizotypy: implications for illness and health. Oxford University Press, Oxford ; New York. [ISBN 019852353X] https://doi.org/10.1093/ med:psych/9780198523536.001.0001

- Collip D, Wigman JT, Myin-Germeys I, Jacobs N, Derom C, Thiery E, Wichers M, van Os $\mathrm{J}$ (2013) From epidemiology to daily life: linking daily life stress reactivity to 
persistence of psychotic experiences in a longitudinal general population study. PLOS One 8 (4): e62688. https://doi.org/10.1371/journal.pone.0062688

- Connelly WM, Laing M, Errington AC, Crunelli V (2015) The Thalamus as a Low Pass Filter: Filtering at the Cellular Level does Not Equate with Filtering at the Network Level. Frontiers in Neural Circuits 9: 89. https://doi.org/10.3389/fncir.2015.00089

- Connolly SD, Bernstein GA, Work Group on Quality I (2007) Practice parameter for the assessment and treatment of children and adolescents with anxiety disorders. Journal of the American Academy of Child \& Adolescent Psychiatry 46 (2): 267-283. https:// doi.org/10.1097/01.chi.0000246070.23695.06

- $\quad$ Corcoran C, Mujica-Parodi L, Yale S, Leitman D, Malaspina D (2002) Could stress cause psychosis in individuals vulnerable to schizophrenia? CNS Spectrums 7 (1): 33-38. https://doi.org/10.1017/S1092852900022240

- $\quad$ Corcoran C, Walker E, Huot R, Mittal V, Tessner K, Kestler L, Malaspina D (2003) The stress cascade and schizophrenia: etiology and onset. Schizophrenia Bulletin 29 (4):

671-692. https://doi.org/10.1093/oxfordjournals.schbul.a007038

- $\quad$ Cornblatt BA, Erlenmeyer-Kimling L (1985) Global attentional deviance as a marker of risk for schizophrenia: specificity and predictive validity. Journal of Abnormal Psychology 94 (4): 470-486. https://doi.org/10.1037/0021-843X.94.4.470

- Crow TJ (1995a) A Darwinian approach to the origins of psychosis. The British Journal of Psychiatry 167 (1): 12-25. https://doi.org/10.1192/bjp.167.1.12

- $\quad$ Crow TJ (1995b) A theory of the evolutionary origins of psychosis. European Neuropsychopharmacology 5 Suppl: 59-63. https://doi.org/10.1016/0924-977X (95)00032-K

- Crow TJ (1998) From Kraepelin to Kretschmer leavened by Schneider: thextransition from categories of psychosis to dimensions of variation intrinsic to homo sapiens. Archives of General Psychiatry 55 (6): 502-504. https://doi.org/10.1001/ archpsyc.55.6.502

- Darwin C (1859) On the origin of species by means of natural selection. J. Murray, London.

- $\quad$ Davidson M, Reichenberg A, Rabinowitz J, Weiser M, Kaplan Z, Mark M (1999) Behavioral and intellectual markers for schizophrenia in apparently healthy male adolescents. The American Journal of Psychiatry 156 (9): 1328-1335. https:// doi.org/10.1176/ajp.156.9.1328

- den Boer PJ (1999) Natural selection or the non-survival of the non-fit. Acta Biotheoretica 47: 83-97. https://doi.org/10.1023/A:1002053820381

- Dorph-Petersen KA, Lewis DA (2011) Stereological approaches to identifying neuropathology in psychosis. Biological Psychiatry 69 (2): 113-126. https:// doi.org/10.1016/i.biopsych.2010.04.030

- Dorph-Petersen KA, Lewis DA (2017) Postmortem structural studies of the thalamus in schizophrenia. Schizophrenia Research 180: 28-35. https://doi.org/10.1016/ j.schres.2016.08.007

- Dubrovsky B (2002) Evolutionary psychiatry. Adaptationist and nonadaptationist conceptualizations. Biological Psychiatry 26 (1): 1-19. https://doi.org/10.1016/ S0278-5846(01)00243-3

- $\quad$ Edwards AC, Bigdeli TB, Docherty AR, Bacanu S, Lee D, de Candia TR, Moscati A, Thiselton DL, Maher BS, Wormley BK, Molecular Genetics of Schizophrenia C, Walsh D, O'Neill FA, Kendler KS, Riley BP, Fanous AH (2016) Meta-analysis of Positive and 
Negative Symptoms Reveals Schizophrenia Modifier Genes. Schizophrenia Bulletin 42 (2): 279-287. https://doi.org/10.1093/schbul/sbv119

- $\quad$ Eichenbaum H (2017) On the Integration of Space, Time, and Memory. Neuron 95 (5): 1007-1018. https://doi.org/10.1016/i.neuron.2017.06.036

- Elvevag B, Goldberg TE (2000) Cognitive impairment in schizophrenia is the core of the disorder. Critical Reviews in Neurobiology 14 (1): 1-21.

- $\quad$ Eranti SV, MacCabe JH, Bundy H, Murray RM (2013) Gender difference in age at onset of schizophrenia: a meta-analysis. Psychological Medicine 43 (1): 155-167. https:// doi.org/10.1017/S003329171200089X

- $\quad$ Erlenmeyer-Kimling L (1968) Mortality rates in the offspring of schizophrenic parents and a physiological advantage hypothesis. Nature 220 (5169): 798-800. https:// doi.org/10.1038/220798a0

- Filley CM, Fields RD (2016) White matter and cognition: making the connection. Journal of Neurophysiology 116 (5): 2093-2104. https://doi.org/10.1152/jn.00221.2016

- Fioravanti M, Carlone O, Vitale B, Cinti ME, Clare L (2005) A meta-analysis of cognitive deficits in adults with a diagnosis of schizophrenia. Neuropsychology Review 15 (2):

73-95. https://doi.org/10.1007/s11065-005-6254-9

- $\quad$ Fioravanti M, Bianchi V, Cinti ME (2012) Cognitive deficits in schizophrenia: an updated metanalysis of the scientific evidence. BMC Psychiatry 12 https://

doi.org/10.1186/1471-244X-12-64

- Fombonne E (2009) Epidemiology of pervasive developmental disorders. Pediatric Research 65 (6): 591-8. https://doi.org/10.1203/PDR.0b013e31819e7203

- Funahashi S (2013) Thalamic mediodorsal nucleus and its participation in spatial working memory processes: comparison with the prefrontal cortex. Frontiers in Systems Neuroscience 7 https://doi.org/10.3389/fnsys.2013.00036

- Giraldo-Chica M, Rogers BP, Damon SM, Landman BA, Woodward ND (2018) Prefrontal-thalamic anatomical connectivity and executive cognitive function in schizophrenia. Biological Psychiatry 83 (6): 509-517. https://doi.org/10.1016/ j.biopsych.2017.09.022

- Goel V, Gold B, Kapur S, Houle S (1998) Neuroanatomical correlates of human reasoning. Journal of Cognitive Neuroscience 10 (3): 293-302. https://

doi.org/10.1162/089892998562744

- Gottesman I, Gould TD (2003) The endophenotype concept in psychiatry: etymology and strategic intentions. The American Journal of Psychiatry 160 (4): 636-45. https:// doi.org/10.1176/appi.ajp.160.4.636

- Habib MR, Ganea DA, Katz IK, Lamprecht R (2013) ABL1 in thalamus is associated with safety but not fear learning. Frontiers in Systems Neuroscience 7 https:// doi.org/10.3389/fnsys.2013.00005

- Hamoda HM, Makhlouf AT, Fitzsimmons J, Rathi Y, Makris N, Mesholam-Gately RI, Wojcik JD, Goldstein J, McCarley RW, Seidman LJ, Kubicki M, Shenton ME (2018) Abnormalities in thalamo-cortical connections in patients with first-episode schizophrenia: a two-tensor tractography study. Brain Imaging and Behavior 1-10. https://doi.org/10.1007/s11682-018-9862-8

- Hare E, Glahn DC, Dassori A, Raventos H, Nicolini H, Ontiveros A, Medina R, Mendoza R, Jerez A, Munoz R, Almasy L, Escamilla MA (2010) Heritability of age of onset of psychosis in schizophrenia. American Journal of Medical Genetics Part B:

Neuropsychiatric Genetics 153B (1): 298-302. https://doi.org/10.1002/ajmg.b.30959 
- Harris EC, Barraclough B (1998) Excess mortality of mental disorder. The British Journal of Psychiatry 173: 11-53. https://doi.org/10.1192/bjp.173.1.11

- Harrison PJ (1999) The neuropathology of schizophrenia. A critical review of the data and their interpretation. Brain: A Journal of Neurology 122: 593-624.

- Harrison PJ, Weinberger DR (2004) Schizophrenia genes, gene expression, and neuropathology: on the matter of their convergence. Molecular Psychiatry 10 https:// doi.org/10.1038/sj.mp.4001558

- Harvey P (2013) Cognitive impairment in schizophrenia: characteristics, assessment, and treatment. Cambridge University Press, Cambridge. [ISBN 9781107013209] https:// doi.org/10.1017/CBO9781139003872

- Hickok G (2009) The functional neuroanatomy of language. Physics of Life Reviews 6 (3): 121-43. https://doi.org/10.1016/j.plrev.2009.06.001

- Hosák L, Hosakova J (2015) The complex etiology of schizophrenia - general state of the art. Neuroendocrinology Letters 36 (7): 631-637.

- Howes OD, McCutcheon R, Owen MJ, Murray RM (2017) The Role of Genes, Stress, and Dopamine in the Development of Schizophrenia. Biological Psychiatry 81 (1): 9-20. https://doi.org/10.1016/i.biopsych.2016.07.014

- Huxley J, Mayr E, Osmond H, Hoffer A (1964) Schizophrenia as a gaenetic morphism. Nature 204: 220-1. https://doi.org/10.1038/204220a0

- Immonen J, Jaaskelainen E, Korpela H, Miettunen J (2017) Age at onset and the outcomes of schizophrenia: A systematic review and meta-analysis. Early Interv Psychiatry 11 (6): 453-460. https://doi.org/10.1111/eip.12412

- Iwamoto K, Bundo M, Ueda J, Oldham MC, Ukai W, Hashimoto E, Saito T, Geschwind DH, Kato T (2011) Neurons show distinctive DNA methylation profile and higher interindividual variations compared with non-neurons. Genome Research 21 (5): 688-96. https://doi.org/10.1101/gr.112755.110

- Jankowski MM, Ronnqvist KC, Tsanov M, Vann SD, Wright NF, Erichsen JT, Aggleton JP, O'Mara SM (2013) The anterior thalamus provides a subcortical circuit supporting memory and spatial navigation. Frontiers in Systems Neuroscience 7: 45. https:// doi.org/10.3389/fnsys.2013.00045

- Jones EG (1997) Cortical development and thalamic pathology in schizophrenia. Schizophrenia Bulletin 23 (3): 483-501. https://doi.org/10.1093/schbul/23.3.483

- Kaymaz N, Drukker M, Lieb R, Wittchen HU, Werbeloff N, Weiser M, Lataster T, van Os $J$ (2012) Do subthreshold psychotic experiences predict clinical outcomes in unselected non-help-seeking population-based samples? A systematic review and meta-analysis, enriched with new results. Psychological Medicine 42 (11): 2239-2253. https:// doi.org/10.1017/S0033291711002911

- $\quad$ Keshavan MS, Nasrallah HA, Tandon R (2011) Schizophrenia, "Just the Facts" 6. Moving ahead with the schizophrenia concept: from the elephant to the mouse. Schizophrenia Research 127 (1-3): 3-13. https://doi.org/10.1016/j.schres.2011.01.011

- Kim Y, Xia K, Tao R, Giusti-Rodriguez P, Vladimirov V, van den Oord E, Sullivan PF (2014) A meta-analysis of gene expression quantitative trait loci in brain. Translational Psychiatry 4: e459. https://doi.org/10.1038/tp.2014.96

- Klostermann F, Krugel LK, Ehlen F (2013) Functional roles of the thalamus for language capacities. Frontiers in Systems Neuroscience 7: 32. https://doi.org/10.3389/

fnsys.2013.00032 
- Kozlenkov A, Roussos P, Timashpolsky A, Barbu M, Rudchenko S, Bibikova M, Klotzle B, Byne W, Lyddon R, Di Narzo AF, Hurd YL, Koonin EV, Dracheva S (2014) Differences in DNA methylation between human neuronal and glial cells are concentrated in enhancers and non-CpG sites. Nucleic Acids Res 42 (1): 109-127. https://doi.org/10.1093/nar/gkt838

- Kozlenkov A, Wang M, Roussos P, Rudchenko S, Barbu M, Bibikova M, Klotzle B, Dwork AJ, Zhang B, Hurd YL, Koonin EV, Wegner M, Dracheva S (2016) Substantial DNA methylation differences between two major neuronal subtypes in human brain. Nucleic Acids Research 44 (6): 2593-2612. https://doi.org/10.1093/nar/gkv1304

- Kuttner RE, Lorincz AB, Swan DA (1967) The schizophrenia gene and social evolution. Psychological Reports 20 (2): 407-412. https://doi.org/10.2466/pr0.1967.20.2.407

- Kwapil TR (1998) Social anhedonia as a predictor of the development of schizophreniaspectrum disorders. Journal of Abnormal Psychology 107 (4): 558-565. https:// doi.org/10.1037/0021-843X.107.4.558

- $\quad$ Ladd-Acosta C, Pevsner J, Sabunciyan S, Yolken RH, Webster MJ, Dinkins T, Callinan PA, Fan JB, Potash JB, Feinberg AP (2007) DNA methylation signatures within the human brain. The American Journal of Human Genetics 81 (6): 1304-1315. https:// doi.org/10.1086/524110

- $\quad$ Lane LW, Luchins DJ (1988) Evolutionary approaches to psychiatry and problems of method. Comprehensive Psychiatry 29 (6): 598-603. https://doi.org/10.1016/0010-440X (88)90080-6

- $\quad$ Li B, Cui LB, Xi YB, Friston KJ, Guo F, Wang HN, Zhang LC, Bai YH, Tan QR, Yin H, Lu $\mathrm{H}$ (2017) Abnormal effective connectivity in the brain is involved in auditory verbal hallucinations in schizophrenia. Neuroscience Bulletin 33 (3): 281-291. https:// doi.org/10.1007/s12264-017-0101-x

- $\quad$ Lichtenstein P, Yip BH, Bjork C, Pawitan Y, Cannon TD, Sullivan PF, Hultman CM (2009) Common genetic determinants of schizophrenia and bipolar disorder in Swedish families: a population-based study. Lancet 373 (9659): 234-9. https://doi.org/10.1016/ S0140-6736(09)60072-6

- $\quad$ Liu NH, Daumit GL, Dua T, Aquila R, Charlson F, Cuijpers P, Druss B, Dudek K, Freeman M, Fujii C, Gaebel W, Hegerl U, Levav I, Munk Laursen T, Ma H, Maj M, Elena Medina-Mora M, Nordentoft M, Prabhakaran D, Pratt K, Prince M, Rangaswamy T, Shiers D, Susser E, Thornicroft G, Wahlbeck K, Fekadu Wassie A, Whiteford H, Saxena $S$ (2017) Excess mortality in persons with severe mental disorders: a multilevel intervention framework and priorities for clinical practice, policy and research agendas. World Psychiatry 16 (1): 30-40. https://doi.org/10.1002/wps.20384

- Lockwood PL (2016) The anatomy of empathy: Vicarious experience and disorders of social cognition. Behavioural Brain Research 311: 255-266. https://doi.org/10.1016/ j.bbr.2016.05.048

- Mah S, Nelson MR, Delisi LE, Reneland RH, Markward N, James MR, Nyholt DR, Hayward N, Handoko H, Mowry B, Kammerer S, Braun A (2006) Identification of the semaphorin receptor PLXNA2 as a candidate for susceptibility to schizophrenia. Molecular Psychiatry 11 (5): 471-478. https://doi.org/10.1038/sj.mp.4001785

- Maj M (2011) Understanding the pathophysiology of schizophrenia: are we on the wrong or on the right track? Schizophrenia Research 127 (1-3): 20-21. https:// doi.org/10.1016/i.schres.2011.01.002 
- Manoach D (2003) Prefrontal cortex dysfunction during working memory performance in schizophrenia: reconciling discrepant findings. Schizophrenia Research 60 (2): 285-298. https://doi.org/10.1016/S0920-9964(02)00294-3

- $\quad$ Marenco S, Stein JL, Savostyanova AA, Sambataro F, Tan HY, Goldman AL, Verchinski BA, Barnett AS, Dickinson D, Apud JA, Callicott JH, Meyer-Lindenberg A, Weinberger DR (2012) Investigation of anatomical thalamo-cortical connectivity and FMRI activation in schizophrenia. Neuropsychopharmacology 37 (2): 499-507. https://doi.org/10.1038/ npp.2011.215

- Markow TA (1994) Developmental instability, its origins and evolutionary implications: proceedings of the International Conference on Developmental Instabilbity, It's Origins and Evolutionary Implications, Tempe, Arizona, 14-15 June 1993. Kluwer Academic, Dordrecht Netherlands, Boston. [ISBN 0792326784] https:// doi.org/10.1007/978-94-011-0830-0

- Mathalon DH, Ford JM (2012) Neurobiology of schizophrenia: search for the elusive correlation with symptoms. Frontiers in Human Neuroscience 6: 136. https:// doi.org/10.3389/fnhum.2012.00136

- $\quad$ McGrath JJ, Hearle J, Jenner L, Plant K, Drummond A, Barkla JM (1999) The fertility and fecundity of patients with psychoses. Acta Psychiatrica Scandinavica 99 (6): 441-446. https://doi.org/10.1111/j.1600-0447.1999.tb00990.x

- $\quad$ Millan MJ, Rivet JM, Gobert A (2016) The frontal cortex as a network hub controlling mood and cognition: Probing its neurochemical substrates for improved therapy of psychiatric and neurological disorders. Journal of Psychopharmacology 30 (11): 1099-1128. https://doi.org/10.1177/0269881116672342

- $\quad$ Miller EK (2000) The prefrontal cortex and cognitive control. Nature Reviews Neuroscience 1 (1): 59-65. https://doi.org/10.1038/35036228

- Minamimoto T, Hori Y, Yamanaka K, Kimura M (2014) Neural signal for counteracting pre-action bias in the centromedian thalamic nucleus. Frontiers in Systems Neuroscience 8: 3. https://doi.org/10.3389/fnsys.2014.00003

- $\quad$ Mitchell AS, Chakraborty S (2013) What does the mediodorsal thalamus do? Frontiers in Systems Neuroscience 7 https://doi.org/10.3389/fnsys.2013.00037

- Muleh S, Carpenter W,J (1973) Clinical psychopathology. Comprehensive Psychiatry 15 (3): 255-256. https://doi.org/10.1016/0010-440X(74)90024-8

- Muller NG, Knight RT (2006) The functional neuroanatomy of working memory: contributions of human brain lesion studies. Neuroscience 139 (1): 51-8. https:// doi.org/10.1016/j.neuroscience.2005.09.018

- Munivenkatappa A, Devi BI, Shukla DP, Rajeswaran J (2016) Role of the thalamus in natural recovery of cognitive impairment in patients with mild traumatic brain injury. Brain Injury 30 (4): 388-392. https://doi.org/10.3109/02699052.2015.1089599

- Nakajima M, Halassa MM (2017) Thalamic control of functional cortical connectivity. Current Opinion in Neurobiology 44: 127-131. https://doi.org/10.1016/ j.conb.2017.04.001

- $\quad$ Neu P, Gooren T, Niebuhr U, Schlattmann P (2017) Cognitive impairment in schizophrenia and depression: A comparison of stability and course. Applied Neuropsychology: Adult 1-14. https://doi.org/10.1080/23279095.2017.1392962

- $\quad$ Ng MY, Levinson DF, Faraone SV, Suarez BK, DeLisi LE, Arinami T, Riley B, Paunio T, Pulver AE, Irmansyah, Holmans PA, Escamilla M, Wildenauer DB, Williams NM, Laurent C, Mowry BJ, Brzustowicz LM, Maziade M, Sklar P, Garver DL, Abecasis GR, 
Lerer B, Fallin MD, Gurling HM, Gejman PV, Lindholm E, Moises HW, Byerley W, Wijsman EM, Forabosco P, Tsuang MT, Hwu HG, Okazaki Y, Kendler KS, Wormley B, Fanous A, Walsh D, O'Neill FA, Peltonen L, Nestadt G, Lasseter VK, Liang KY, Papadimitriou GM, Dikeos DG, Schwab SG, Owen MJ, O'Donovan MC, Norton N, Hare E, Raventos H, Nicolini H, Albus M, Maier W, Nimgaonkar VL, Terenius L, Mallet J, Jay M, Godard S, Nertney D, Alexander M, Crowe RR, Silverman JM, Bassett AS, Roy MA, Merette C, Pato CN, Pato MT, Roos JL, Kohn Y, Amann-Zalcenstein D, Kalsi G, McQuillin A, Curtis D, Brynjolfson J, Sigmundsson T, Petursson H, Sanders AR, Duan J, Jazin E, Myles-Worsley M, Karayiorgou M, Lewis CM (2009) Meta-analysis of 32 genome-wide linkage studies of schizophrenia. Molecular Psychiatry 14 (8): 774-85. https://doi.org/10.1038/mp.2008.135

- O'Donovan MC, Craddock N, Norton N, Williams H, Peirce T, Moskvina V, Nikolov I, Hamshere M, Carroll L, Georgieva L, Dwyer S, Holmans P, Marchini JL, Spencer CC, Howie B, Leung HT, Hartmann AM, Moller HJ, Morris DW, Shi Y, Feng G, Hoffmann P, Propping P, Vasilescu C, Maier W, Rietschel M, Zammit S, Schumacher J, Quinn EM, Schulze TG, Williams NM, Giegling I, Iwata N, Ikeda M, Darvasi A, Shifman S, He L, Duan J, Sanders AR, Levinson DF, Gejman PV, Cichon S, Nothen MM, Gill M, Corvin A, Rujescu D, Kirov G, Owen MJ, Buccola NG, Mowry BJ, Freedman R, Amin F, Black DW, Silverman JM, Byerley WF, Cloninger CR, Molecular Genetics of Schizophrenia C (2008) Identification of loci associated with schizophrenia by genome-wide association and follow-up. Nature Genetics 40 (9): 1053-1055. https://doi.org/10.1038/ng.201

- $\quad$ Olfson M, Gerhard T, Huang C, Crystal S, Stroup TS (2015) Premature mortality among adults with schizophrenia in the United States. JAMA Psychiatry 72 (12): 1172-1181. https://doi.org/10.1001/jamapsychiatry.2015.1737

- $\quad$ Ostendorf F, Liebermann D, Ploner CJ (2013) A role of the human thalamus in predicting the perceptual consequences of eye movements. Frontiers in Systems Neuroscience 7 https://doi.org/10.3389/fnsys.2013.00010

- Owen MJ, Craddock N, O'Donovan MC (2005) Schizophrenia: genes at last? Trends in Genetics 21 (9): 518-525. https://doi.org/10.1016/j.tig.2005.06.011

- Paus T, Keshavan M, Giedd JN (2008) Why do many psychiatric disorders emerge during adolescence? Nature Reviews Neuroscience 9 (12): 947-957. https:// doi.org/10.1038/nrn2513

- Paus T (2010) Sex differences in the human brain: a developmental perspective. Progress in Brain Research 186: 13-28. https://doi.org/10.1016/ B978-0-444-53630-3.00002-6

- Pearlson GD, Folley BS (2008) Schizophrenia, psychiatric genetics, and Darwinian psychiatry: an evolutionary framework. Schizophrenia Bulletin 34 (4): 722-733. https:// doi.org/10.1093/schbul/sbm130

- Penner J, Osuch EA, Schaefer B, Theberge J, Neufeld RWJ, Menon RS, Rajakumar N, Bourne JA, Williamson PC (2018) Higher order thalamic nuclei resting network connectivity in early schizophrenia and major depressive disorder. Psychiatry Research Neuroimaging 272: 7-16. https://doi.org/10.1016/j.pscychresns.2017.12.002

- Polimeni J, Reiss JP (2003) Evolutionary perspectives on schizophrenia. Canadian Journal of Psychiatry 48 (1): 34-39. https://doi.org/10.1177/070674370304800107

- Power RA, Kyaga S, Uher R, MacCabe JH, Langstrom N, Landen M, McGuffin P, Lewis CM, Lichtenstein P, Svensson AC (2013) Fecundity of patients with schizophrenia, autism, bipolar disorder, depression, anorexia nervosa, or substance abuse vs their 
unaffected siblings. JAMA Psychiatry 70 (1): 22-30. https://doi.org/10.1001/ jamapsychiatry.2013.268

- $\quad$ Prevosto V, Sommer MA (2013) Cognitive control of movement via the cerebellarrecipient thalamus. Frontiers in Systems Neuroscience 7 https://doi.org/10.3389/ fnsys.2013.00056

- $\quad$ Ramirez-Cardenas A, Viswanathan P (2016) The role of prefrontal mixed selectivity in cognitive control. The Journal of Neuroscience 36 (35): 9013-9015. https:// doi.org/10.1523/JNEUROSCI.1816-16.2016

- Randall PL (1983) Schizophrenia, abnormal connection, and brain evolution. Medical Hypotheses 10 (3): 247-280. https://doi.org/10.1016/0306-9877(83)90114-7

- Rosenthal CR, Soto D (2016) The anatomy of non-conscious recognition memory. Trends in Neurosciences 39 (11): 707-711. https://doi.org/10.1016/j.tins.2016.09.005

- Rund BR (1998) A review of longitudinal studies of cognitive functions in schizophrenia patients. Schizophrenia Bulletin 24 (3): 425-435. https://doi.org/10.1093/ oxfordjournals.schbul.a033337

- Saalmann YB (2014) Intralaminar and medial thalamic influence on cortical synchrony, information transmission and cognition. Frontiers in Systems Neuroscience 8: 83. https://doi.org/10.3389/fnsys.2014.00083

- Saha S, Chant D, McGrath J (2007) A systematic review of mortality in schizophrenia: is the differential mortality gap worsening over time? Arch Gen Psychiatry 64 (10): 1123-1131. https://doi.org/10.1001/archpsyc.64.10.1123

- Saugstad LF (1989) Age at puberty and mental illness. Towards a neurodevelopmental aetiology of Kraepelin's endogenous psychoses. The British Journal of Psychiatry 155: 536-544. https://doi.org/10.1192/bjp.155.4.536

- $\quad$ Sayo A, Jennings R, Van Horn JD (2012) Study factors influencing ventricular enlargement in schizophrenia: A 20 year follow-up meta-analysis. Neurolmage 59 (1): 154-167. https://doi.org/10.1016/i.neuroimage.2011.07.011

- Schneider K (1959) Clinical psychopathology. Grune \& Stratton, New York,.

- $\quad$ Shepherd AM, Laurens KR, Matheson SL, Carr VJ, Green MJ (2012) Systematic metareview and quality assessment of the structural brain alterations in schizophrenia. Neuroscience \& Biobehavioral Reviews 36 (4): 1342-1356. https://doi.org/10.1016/ j.neubiorev.2011.12.015

- $\quad$ Sherman SM (2017) Functioning of Circuits Connecting Thalamus and Cortex. Comprehensive Physiology 7 (2): 713-739. https://doi.org/10.1002/cphy.c160032

- Shifman S, Johannesson M, Bronstein M, Chen SX, Collier DA, Craddock NJ, Kendler KS, Li T, O'Donovan M, O'Neill FA, Owen MJ, Walsh D, Weinberger DR, Sun C, Flint J, Darvasi A (2008) Genome-wide association identifies a common variant in the reelin gene that increases the risk of schizophrenia only in women. PLoS Genetics 4 (2): e28. https://doi.org/10.1371/journal.pgen.0040028

- Shipony Z, Mukamel Z, Cohen NM, Landan G, Chomsky E, Zeliger SR, Fried YC, Ainbinder E, Friedman N, Tanay A (2014) Dynamic and static maintenance of epigenetic memory in pluripotent and somatic cells. Nature 513 (7516): 115-119. https:// doi.org/10.1038/nature13458

- $\quad$ Siever LJ, Kalus OF, Keefe RS (1993) The boundaries of schizophrenia. Psychiatric Clinics of North America 16 (2): 217-244. https://doi.org/10.1016/S0193-953X (18)30171-0 
- $\quad$ Srinivasan S, Bettella F, Mattingsdal M, Wang Y, Witoelar A, Schork AJ, Thompson WK, Zuber V, Schizophrenia Working Group of the Psychiatric Genomics Consortium TIHGC, Winsvold BS, Zwart JA, Collier DA, Desikan RS, Melle I, Werge T, Dale AM, Djurovic S, Andreassen OA (2016) Genetic Markers of Human Evolution Are Enriched in Schizophrenia. Biological Psychiatry 80 (4): 284-292. https://doi.org/10.1016/ j.biopsych.2015.10.009

- Stefanis NC, Hanssen M, Smirnis NK, Avramopoulos DA, Evdokimidis IK, Stefanis CN, Verdoux $\mathrm{H}$, Van Os J (2002) Evidence that three dimensions of psychosis have a distribution in the general population. Psychological Medicine 32 (2): 347-358. https:// doi.org/10.1017/S0033291701005141

- Stevens A, Price J (1996) Evolutionary Psychiatry: A New Beginning. Routledge, London, New York. [ISBN $0415138396041513840 X]$

- Takahashi H, Katayama K, Sohya K, Miyamoto H, Prasad T, Matsumoto Y, Ota M, Yasuda H, Tsumoto T, Aruga J, Craig AM (2012) Selective control of inhibitory synapse development by Slitrk3-PTPdelta trans-synaptic interaction. Nature Neuroscience 15 (3): 389-398. https://doi.org/10.1038/nn.3040

- Talonen S, Vaananen J, Kaltiala-Heino R (2017) Gender differences in first onset Schizophrenia spectrum psychoses. Nordic Journal of Psychiatry 71 (2): 131-138. https://doi.org/10.1080/08039488.2016.1245783

- Thune JJ, Uylings HB, Pakkenberg B (2001) No deficit in total number of neurons in the prefrontal cortex in schizophrenics. Journal of Psychiatric Research 35 (1): 15-21. https://doi.org/10.1016/S0022-3956(00)00043-1

- $\quad$ Tost H, Champagne FA, Meyer-Lindenberg A (2015) Environmental influence in the brain, human welfare and mental health. Nature Neuroscience 18 (10): 1421-1431. https://doi.org/10.1038/nn.4108

- Tsuang M, Simpson J (1988) Nosology, Epidemiology, and Genetics of Schizophrenia. Elsevier, Amsterdam, New York. [ISBN 0444904662]

- Urdinguio RG, Sanchez-Mut JV, Esteller M (2009) Epigenetic mechanisms in neurological diseases: genes, syndromes, and therapies. Lancet Neurology 8 (11): 1056-1072. https://doi.org/10.1016/S1474-4422(09)70262-5

- $\quad$ van der Steen Y, Myin-Germeys I, van Nierop M, Ten Have M, de Graaf R, van Dorsselaer S, van Os J, van Winkel R (2018) 'False-positive' self-reported psychotic experiences in the general population: an investigation of outcome, predictive factors and clinical relevance. Epidemiology and Psychiatric Sciences 1-12. https:// doi.org/10.1017/S2045796018000197

- $\quad$ van Dongen J, Boomsma DI (2013) The evolutionary paradox and the missing heritability of schizophrenia. American Journal of Medical Genetics Part B: Neuropsychiatric Genetics 162B (2): 122-136. https://doi.org/10.1002/ajmg.b.32135

- van Os J, Hanssen M, Bijl RV, Ravelli A (2000) Strauss (1969) revisited: a psychosis continuum in the general population? Schizophrenia Research 45 (1-2): 11-20. https:// doi.org/10.1016/S0920-9964(99)00224-8

- $\quad$ van Os J, Linscott RJ, Myin-Germeys I, Delespaul P, Krabbendam L (2009) A systematic review and meta-analysis of the psychosis continuum: evidence for a psychosis proneness-persistence-impairment model of psychotic disorder. Psychological Medicine 39 (2): 179-195. https://doi.org/10.1017/S0033291708003814

- van Os J, Kenis G, Rutten BP (2010) The environment and schizophrenia. Nature 468 (7321): 203-212. https://doi.org/10.1038/nature09563 
- Verdoux H, Maurice-Tison S, Gay B, Van Os J, Salamon R, Bourgeois ML (1998a) A survey of delusional ideation in primary-care patients. Psychological Medicine 28 (1): 127-34. https://doi.org/10.1017/S0033291797005667

- Verdoux H, van Os J, Maurice-Tison S, Gay B, Salamon R, Bourgeois M (1998b) Is early adulthood a critical developmental stage for psychosis proneness? A survey of delusional ideation in normal subjects. Schizophrenia Research 29 (3): 247-254. https:// doi.org/10.1016/S0920-9964(97)00095-9

- Vollema MG, Sitskoorn MM, Appels MC, Kahn RS (2002) Does the Schizotypal Personality Questionnaire reflect the biological-genetic vulnerability to schizophrenia? Schizophrenia Research 54 (1-2): 39-45. https://doi.org/10.1016/S0920-9964 (01)00350-4

- Weinberger D, Berman KF (1998) Prefrontal function in schizophrenia: confounds and controversies. In: Roberts AC, Robbins TW, Weiskrantz L (Eds) The Prefrontal CortexExecutive and Cognitive Functions. Oxford Scholarship Online https:// doi.org/10.1093/acprof:oso/9780198524410.003.0012

- Yung AR, Phillips LJ, Yuen HP, Francey SM, McFarlane CA, Hallgren M, McGorry PD (2003) Psychosis prediction: 12-month follow up of a high-risk ("prodromal") group. Schizophrenia Research 60 (1): 21-32. https://doi.org/10.1016/S0920-9964(02)00167-6

- Zaytseva Y, Kozakova E, Bakstein E, Hlinka J, Schutte M, Sommer I, Horacek J, Spaniel F (2018) Thalamic-cortical connectivity in patients with auditory hallucinations in schizophrenia. Schizophrenia Bulletin 44 (Suppl 1): S173. https://doi.org/10.1093/ schbul/sby016.424

- Zola-Morgan S, Squire LR (1993) Neuroanatomy of memory. Annual Review in Neurosceince 16: 547-563. https://doi.org/10.1146/annurev.ne.16.030193.002555 